\title{
An inquiry into the transformation of the PR roles' concept
}

ARTICLE in CORPORATE COMMUNICATIONS AN INTERNATIONAL JOURNAL · JANUARY 2015

DOI: 10.1108/CCIJ-02-2014-0013

3 AUTHORS:

\section{Christian Fieseler}

BI Norwegian Business School

72 PUBLICATIONS 105 CITATIONS

SEE PROFILE

Miriam Meckel

University of St.Gallen

216 PUBLICATIONS 231 CITATIONS

SEE PROFILE

\section{Christoph Lutz}

University of St.Gallen

30 PUBLICATIONS 24 CITATIONS

SEE PROFILE 


\section{Emerald Insight}

\section{Corporate Communications: An International Journal}

An inquiry into the transformation of the PR roles' concept:

Christian Fieseler Christoph Lutz Miriam Meckel

\section{Article information:}

To cite this document:

Christian Fieseler Christoph Lutz Miriam Meckel , (2015),"An inquiry into the transformation of the PR roles' concept", Corporate Communications: An International Journal, Vol. 20 Iss 1 pp. -

Permanent link to this document:

http://dx.doi.org/10.1108/CClJ-02-2014-0013

Downloaded on: 22 December 2014, At: 13:17 (PT)

References: this document contains references to 0 other documents.

To copy this document: permissions@emeraldinsight.com

Access to this document was granted through an Emerald subscription provided by 322475 []

\section{For Authors}

If you would like to write for this, or any other Emerald publication, then please use our Emerald for Authors service information about how to choose which publication to write for and submission guidelines are available for all. Please visit www. emeraldinsight. com/authors for more information.

\section{About Emerald www.emeraldinsight.com}

Emerald is a global publisher linking research and practice to the benefit of society. The company manages a portfolio of more than 290 journals and over 2,350 books and book series volumes, as well as providing an extensive range of online products and additional customer resources and services.

Emerald is both COUNTER 4 and TRANSFER compliant. The organization is a partner of the Committee on Publication Ethics (COPE) and also works with Portico and the LOCKSS initiative for digital archive preservation. 


\section{An Inquiry into the Transformation of the PR Roles' Concept}

\section{Introduction}

Research into the roles of communication practitioners represents one of the dominant themes within the public relations literature, driven by the desire to establish public relations as a proper profession (Cameron, Sallot, \& Weaver-Lariscy, 1996; Grunig, 2000). Roles research started with Broom and Smith's (1979) four role typology, and continued with Dozier's (1984) refinement into a manager-technician dichotomy and Toth, Serini, Wright and Emig's (1998) subsequent addition of a third dominant role to this dichotomy, termed the agency profile. The seminal work in the field is Dozier and Broom's (1995) reconceptualization of their original findings. They posited a number of key antecedents affecting practitioners' ability to enact manager roles. In particular, they stressed the effect of gender, professional experience, tenure with an employer, education, and public relations department size. Already then, they observed decreasing effects in their model, for instance regarding differences due to gender compared to prior studies (Dozier, 1984). However, the mentioned replication study (Dozier \& Broom, 1995) uses data from 1991, and since then further changes are likely to have occurred. Furthermore, the majority of roles studies focus on US practitioners. Their experience may not necessarily be representative of public relations industries in other countries (Moss, Warnaby, \& Newman, 2000). Accordingly, in recent years, there has been renewed interest in the European (e.g., Tench, Zerfass, Verhoeven, Verčič, Moreno \& Okay, 2013; Zerfass, Verhoeven, Tench, Moreno, \& Verčič, 2011) and Asian perspective (e.g. Choi, 2007).

1

(C) Emerald Group Publishing Limited

This is a pre-print of a paper and is subject to change before publication. This pre-print is made available with the understanding that it will not be reproduced or stored in a retrieval system without the permission of Emerald Group Publishing Limited. 
Of particular interest in roles research is manager roles enactment, as one of the primary factors that characterize excellent public relations practices (Grunig, Grunig, \& Dozier, 2002). Here, scholars such as Leichty and Springston (1996), Moss, Newman, and DeSanto (2005), Choi (2007) or Porter and Sallot (2003) have argued that the discussion about the manager-technician dichotomy might obscure examining the more specific determinants and outcomes of the manager role, and that more analysis is needed to understand the proper managerial tasks of the profession. Already, scholars such as Berger and Reber (2006), Berger, Reber and Heyman (2007), DeSanto and Moss (2004), Gregory and Willis (2013), Moss and Green (2001), Moss et al. (2005) as well as Moss et al. (2000) started to enlarge the conversation by discussing the managerial role not only in the specific terms of public relations, but opening it up to the wider perspective in general management on professional roles. Many of these discussions are led with reference to the purposes of the activities that public relations managers enact, but not necessarily related to the personal characteristics needed to fulfilling a particular role, and the personal outcomes a manager might expect in terms of job satisfaction and participation in deliberating organizational strategy.

In this paper, we are interested in what defines and what results from being a communication manager, complimenting previous studies in US settings with European data. First, we intend to unfold the different managerial tasks that define the particular managerial role a communicator plays in his or her organization. We think it is important to reconsider the managerial task components as they are often obscured by the manager vs. technician debate, and because a profession that is still constantly redefining its place in many organizations, not least because of recent developments such as increasing stakeholder activism and 
technological innovations such as social media, necessitate frequent reconsiderations of what it entails to be a communication manager. We will then go on to enquire what particular characteristics in terms of experience and gender are good predictors of managerial role enactment, thus complementing the ongoing discussion by a European perspective. Similarly, we are interested in the personal outcomes of managerial role enactment, in terms of satisfaction, remuneration, and participation in organizational decision-making, and again differentiated by different managerial task components.

\section{Theoretical Background}

Dozier and Broom (1995) ask which determinants affect practitioners' professional achievements. They are primarily interested in public relations (PR) practitioners' job satisfaction and salary as outcome variables, and distinguish two basic PR roles: a manager role and a technician role. The manager role entails the problem-solving processes facilitation, communication facilitation, and expert prescription. Exemplary responsibilities and tasks for this type include "I diagnose public relations problems and explain them to others in the organization”, “I take responsibility for the success or failure of my organization's public relations program", and "I report public opinion survey results to keep management informed of the opinions of various publics". On the other hand, the technician role covers the technical aspects of PR. Sample activities for the technician role are "I produce brochure, pamphlets, and other publications", "I do photography and graphics for public relations materials" or "writing public relations materials presenting information on issues important to the organization". The manager role itself is divided into three sub-types, 
which are called "expert prescriber" (EP), "process facilitator" (PF), and "communication facilitator" (CF). However, the technician role type is not divided into sub-types.

These roles form the core of Dozier and Broom's PR model, which is shown in figure 1. It proposes an explanation for differences in job satisfaction and salary between PR professionals. The roles are themselves (directly) influenced by professional experience, education, gender, and PR staff size.

\section{FIGURE 1 Dozier and Broom's PR model ABOUT HERE}

The role enactment model was first tested with US data from 1979 (Broom, 1982) and subsequently replicated in a Public Relations Society of America (PRSA) membership survey in 1991 (Dozier \& Broom, 1995). Gender and Professional Experience were the two most important determinants of manager roles in 1979. The effect of gender weakened over time, and in 1991, the direct effects of education and PR staff size on PR professionals' manager role were substantially higher than the gender effects.

Several severe points of criticism have been raised regarding the main specifications and findings of Dozier and Broom's PR model. At their very core, roles are, and have to be, as Lauzen and Dozier (1992) note, abstractions of the real activities that practitioners perform. This makes conceptualizing and measuring roles inherently problematic.

Practitioner roles research has been largely based on the same measure: a 24-item battery with role activities developed by Broom (1982) as an index of the four conceptual roles advanced by Broom \& Smith (1979), or Dozier's (1984) manager-technician dichotomy. Already Leichty and Springston (1996) have suggested that a lot of meaningful information may be lost by categorizing practitioners as either simply managers or technicians. Adding 
to this criticism, Toth et al. (1998) warned against the danger of thinking that the work of all technicians is similar, and completely distinct from the managers, thus agreeing with Leichty and Springston's (1996) point that the items comprising the management role scale might, in fact, be labeled 'the everything other than technical activities scale'. Similarly, Moss et al. (2000) have pointed out that most roles studies have failed to distinguish between 'managerial tasks and responsibilities' and 'managerial behaviors' and thus offer only limited insights into how practitioners may perform the 'managerial duties'. Newer research tends to stress the importance of applying appropriate leadership styles in public relations practice, to influence organizational decisions and values (Berger \& Reber, 2006; Berger, Reber, \& Heyman, 2007; Gregory \& Willis (2013).

In the last years, there have been various initiatives toward a better understanding of public relations (PR) practitioners and their respective roles (Moss et al., 2000; Tench et al., 2000; Zerfass et al., 2011;), and towards improving the measurements for the work elements performed by public relations managers (Moss et al., 2005; DeSanto et al., 2007).

There is also strong interest in the issue of the power public relations may or may not exert within organizations (e.g., Berger, 2005). This discussion about PR's place at the table entails to which degree communication managers are able to influence an organization's decision making. The question of participation is considered as important as outlined by Grunig et. al. (2002), because the strategic decisions an organizations is taking have an effect on the audiences of public relations, the organization's stakeholder, therefore involvement in the decision making process is critical both to achieve optimum results as well as to prepare communications. Senior communicator's participation in deliberating strategy has thus been identified as a characteristic of an excellent communications department (Grunig 
et al., 2002). Previous research points to a connection between managerial role enactment and participation in decision-making (Broom, 1982; Dozier \& Broom, 1995). Likewise, Gordon and Kelly (1999) reported that manager role competencies in the public relations department are positively related to public relations' participation in strategic planning. On the flipside research was unable to show any significant impact of technician role enactment to participation in organizational decision-making processes (Broom, 1982).

\section{Methodology}

We use data from a survey conducted with the European Association of Communication Directors (EACD) among marketing and public relations professionals in late 2010 / early 2011 to test the roles model for the European context. The resulting sample of 588 cases was drawn from the following countries, to exclude too large inter-country heterogeneities: Austria, Belgium, France, Germany, Luxembourg, Netherlands, Switzerland, and the United Kingdom. The following table shows the basic distribution and the most important demographic characteristics of the data.

\section{TABLE 1 Sample Description, Percentages ABOUT HERE}

The sample consists of highly educated and rather young professionals (the average age is 39.9 years). Women outweigh men slightly, but the unequal distribution is not alarming, in that in the communication profession female professionals tend to be in the majority, also the sample distribution is similar to comparable European studies on the profession, such as the long-running Communication Monitor. In accordance with the low age, few respondents have more than 15 years of professional experience and only a very small minor- 
ity of about 2 percent has been into PR for 30 years or more. Due to missing values on several variables (mainly salary), only 551 respondents entered the final structural equation model.

We closely aligned with previous research by Dozier and Broom (1995), but modernized the items. We built upon Moss et al.'s (2005) measurement scale for public relations manager roles, and we employed exploratory factor analysis (EFA) on our sample. This yielded four distinct sets of roles: diagnosis, coaching, liaison, and execution. The roles will be discussed in the results section further below.

\section{Results and Discussion}

\subsection{Exploratory Factor Analysis and Group Classification}

We used 19 items for the EFA to identify the PR roles, depicted in the lower part of table 2. One of the original items ("I supervise the web presence of my organization") was dropped because of low factor loadings on every factor, and another item ("Usually I am responsible for handling initial contacts from the media"), because it did not load uniquely on one factor. We used normal principal component extraction with Kaiser Criterion (Eigenvalue $>1$ ) and applied Varimax rotation for the better interpretation of the solution. As for the quality of the EFA, the KMO score of 0.883 indicated almost "marvelous" sampling adequacy (Kaiser \& Rice, 1974). 67 percent of the total variance was explained by the constructs. The analysis yielded four factors, which we termed "Diagnosis" (1), "Coaching" (2), "Liaison" (3), and "Execution" (4). Each of the factors has satisfying reliability, as indicated by their Cronach's $\alpha$ value: $0.921,0.855,0.841$, and 0.778 in respective order - all of which are above the threshold of 0.7 (Nunnally, 1978, p. 245). 
(1) Of the four factors, "Diagnosis" loads highly on ten items and is responsible for 35 percent of the total variance. Diagnosis is about helping circulate information and stakeholder demands in the organization and to decision-makers in a useful format. For this, diagnosis includes internal and external boundary spanning with members of different groups inside and outside the organization. Although this role is important to the efficient and effective operation of organizations, it predominantly contains tasks that are behind-the-scenes and technical.

(2) The second factor, "Coaching" is responsible for 17 percent of the total variance and has three items it is highly connected to. It shows alternative approaches to management for (communication) problem solving, increasing skills in solving and/or avoiding communication problems, and encouraging management participation in making important communication decisions. Thus, respondents who have high factor values on this construct often act as advisors and counselors for management. Coaching primarily relates to communication and soft-skill issues, for which general management needs specialists to train and prepare them for both public appearances as well as managing their teams.

(3) Third, the "Liaison" factor covers activities such as maintaining media contacts and placing press releases, producing communication content for publication and organizing presentations. The factor accounts for 10 percent of the total variance and includes three items. Professionals enacting this role are responsible for the communication with external stakeholders, and hence interact with press and media contacts. Dozier \& Broom (1995, p. 8) coined the term "journalist in residence," which relates very well to this factor. It entails drafting speeches for the executive management, arranging speaking engagements and acting as an in-house ghostwriter. 
(4) Finally, the "Execution" factor is responsible for identifying communication problems and acting upon them. This is the weakest factor with three items, explaining only 5 percent of variance. Furthermore it shares relatively high cross loadings with "Coaching". Therefore, Execution is a more problematic construct, and addresses more technical and organizational activities surrounding the direct diagnosis and acting upon non-mediated stakeholder interaction.

The factors outlined above coincide partly with the Dozier and Broom (1995) solution, but also partly differ. They seem to be more closely related to the factors proposed by Moss et al. (2005). The first and third factors, diagnosis and liaison tend more to the technical side of the manager-technician spectrum proposed by Dozier and Broom (1995), whereas coaching and execution tend to the more managerial aspect of the spectrum. Compared to the Moss et al. (2005) roles, which abandon the manager-technician duality in favor of a fiverole framework, the roles of Monitor and Evaluator, Issue Management Expert as well as Key Policy and Strategy Advisor relate to the coaching and liaison factors, whereas the Trouble-shooter Problem-solver and Communication Technician relate to the diagnosis and execution factor respectively.

\subsection{Structural Equation Model}

Based on Dozier and Broom's (1995)'s original model, we built a SEM that incorporates the PR roles as outlined in the preceding section 4.1. All statistical criteria were fully satisfied, so that we could proceed with the actual model. The loadings and $\mathrm{R}^{2}$ of all items are well above threshold levels, i. e. 0.5 for $\mathrm{R}^{2}$ and $0.5-0.7$ for the factor loadings, according to Bollen, (1989), as well as Netemeyer, Bearden, and Sharma (2003). As depicted in table 2, the Cronbach's $\alpha$ values indicate high reliability and consistency of the scales. Construct 
validity was reached, as Composite Reliability (C.R.) and Average Variance Extracted (AVE) yielded good values, thus indicating convergent validity. The Fornell Larcker criteria were satisfied as well, thus indicating discriminant validity (Fornell \& Larcker, 1981).

\section{TABLE 2 Measurement Model ABOUT HERE}

As for the actual SEM, we computed the model separately for all four factors. In order to account for non-normality of the variables, we used robust Maximum Likelihood estimation (MLR estimator in MPLUS) ${ }^{1}$. In this model, the factor scores from the EFA indicate each person's connectedness to the items associated with the factor. Hence, in total we computed four models: the Diagnosis Model (Factor 1 Model), the Coaching Model (Factor 2 Model), the Liaison Model (Factor 3 Model), and the Execution Model (Factor 4 Model). These are listed in table 3 below.

\section{TABLE 3 Models according to Factors ABOUT HERE}

Diagnosis (Model Fit Values: Chi-Square $=133.43(\mathrm{df}=66)$, RMSEA $=.06, \mathrm{CFI}=.98, \mathrm{TLI}=.97$, $\mathrm{SRMR}=.05$ ) proves to be most satisfying task. Furthermore, it is positively associated with participation in management decision-making, but also requires experience. Thus, PR managers with high values for the diagnosis score are more satisfied with their jobs and have higher share in management decision-making compared with those scoring low on this factor. In sum, having many diagnosis tasks leads to positive outcomes.

By contrast, coaching (Model Fit Values: Chi-Square= $134.43(\mathrm{df}=66)$, RMSEA= .05, CFI= .98, $\mathrm{TLI}=.97, \mathrm{SRMR}=.05)$ is the least satisfying task and also the only one that affects salary

\footnotetext{
${ }^{1}$ The dataset, MPlus and SPSS Syntax of all procedures is available upon request.
} 
negatively. Individuals whose coaching activities are very pronounced are less satisfied and earn less than those with high values on other factors. In general, having many coaching tasks leads to negative outcomes.

Liaison (Model Fit Values: Chi-Square $=130.94(\mathrm{df}=66), \mathrm{RMSEA}=.04, \mathrm{CFI}=.98, \mathrm{TLI}=.97$, $\mathrm{SRMR}=.05$ ) is a weakly defined role that is not affected by gender, professional experience, education and PR staff size. In terms of outcomes, PR managers strong on liaison tend to exert more influence, as they participate more in management decision-making. However, they are slightly less satisfied with their work than those who mainly diagnose, coach, or execute. In sum, liaison is an ambiguous role that might need further clarification.

Finally execution (Model Fit Values: Chi-Square $=131.50(\mathrm{df}=66), \mathrm{RMSEA}=.04, \mathrm{CFI}=.98, \mathrm{TLI}=$ .97 , SRMR $=.05$ ) is the only factor affected by education. Interestingly, more experience and lower education coincide with high levels of execution. The experience factor prevails over the education factor, as high levels of execution influence participation in management decision-making positively. Compared to the other factors, execution is the only one that significantly affects PR managers' salary in a positive way, although the effect is weak.

\subsubsection{Determinants}

As previous research has shown, managerial roles are determined to a certain extent by a number of demographic and workplace antecedents. In the original model, the following variables are held to influence PR practitioners' roles: gender, professional experience (which is in turn influenced by tenure), education, and PR staff size. In the following sections, we briefly summarize the influence of these antecedents on each role identified and on the other dependent variables in the model. 


\section{Gender}

None of the roles was strongly related to gender. Only "Execution" showed a weak, but significant positive path. Thus, male PR professionals tend to be more involved into execution than their female counterparts. However, apart from that observation, no remarkable gender patterns are observed. Neither men nor women in the European PR context are especially prone to carry out diagnosis, coaching, and liaison roles, contradicting Dozier and Broom's (1995) findings for the US.

Gender, however, has a significant and substantial effect on one's salary, tenure and professional experience. The positive sign implies a higher wage and more professional experience for men compared with women. For this gender disparity in salaries, several interpretations are forwarded, among others experience, type of organization in which the public relations person works, and public relations roles (Grunig et al., 2002, p. 209-219). We come back to this point in more detail in the following section, however, judging from the data, these discrepancies seem to have more to do with different salary negotiation tactics, and women attempting more to balance work and family which limits salary levels, as Aldoory and Toth (2002, p. 123) proposed, then with specific roles.

\section{Education and Professional Tenure}

Education is not strongly related to the manager roles, except for execution, where we find a negative effect, as expected. Two of the four roles are positively associated with work experience, and two show no tendency at all. For PR practitioners strong on diagnosis and execution work experience is a strong positive predictor. Thus, the PR roles in the European context - and especially the distinction between more managerial and technical tasks - seem to be defined by education and work experience rather than by gender. 


\section{PR Staff Size}

Finally, PR staff size does not significantly influence the manager roles, except for Coaching, which is negatively affected. Thus, the larger a PR department, the less prevalent the Coaching role becomes. Or in other words, the Coaching role seems to thrive in smaller organizations rather than large ones. Again, the weak or non-existent effects indicate a plurality of roles, which does not depend heavily on contextual characteristics.

\section{Summary of Antecedents}

The overall picture points to a weak determination of the PR roles by the antecedents specified in the original model. The low $\mathrm{R}^{2}$ values indicate that hardly any variance in respondents' roles is explained by gender, education, work experience and PR staff size. Thus, the integration of "soft" - more psychological, individual and motivational - antecedents could be a promising approach to counter the PR professions' weakening determination by "hard factors" or environmental factors, such as gender, work experience, education, and PR staff size.

\subsubsection{Outcomes}

Next to the antecedents, outcomes of PR roles are of crucial interest. This is the litmus test for each role typology, since roles should be meaningful and able to "explain something". Otherwise, the typology would be very contestable and lack theoretical value. Salient outcomes, as specified by Dozier and Broom (1995) are participation in management decisions making, salary, and job satisfaction. We discuss how the PR roles affect each of these constructs in the following paragraphs.

\section{Participation in Management Decision Making (PIMDM)}


Which of the roles is the most "senior" and influential in terms of decision-making? As it turns out, all the roles have a strong and positive influence on PIMDM, except for Coaching. We detect the strongest influence for the last factor, i.e. Execution. As pointed out earlier, the Coaching role is related to negative outcomes in general. Thus, the non-significant path can be interpreted in this regard.

\section{Salary}

Two of the four PR roles do not influence the salary. This is true for Diagnosis and Liaison. The non-significant relationship between these roles and respondents' salary might be due to the influence of other factors. Especially work experience is a strong predictor and takes away much of the variance. For two roles, by contrast, we do find significant role effects on the salary levels. While Coaching negatively - and strongly - impacts professionals' salary, Execution has a positive influence. Execution is a relatively straightforward role heavily formed by respondents' work experience and routine (there is a significant and positive correlation between age and this role factor as well). These facts manifest themselves in higher salary levels for people with high scores on this factor.

Interestingly, salary is a weak determinant of job satisfaction, as the only weakly significant and small effects show. The finding might at least partially be caused by the (relatively) uniform sample and small variance of the salaries. It seems that the decision to work in communications is not so much driven by monetary than by other motives. For the Coaching role, increased salaries do not lead to more job satisfaction at all, while for the other three roles, more money coincides with slightly higher levels of job satisfaction. Again, the Coaching role seems to be a desirable and positive role, driven by intrinsic rather than extrinsic motivation. 


\section{Job Satisfaction}

Finally, job satisfaction is the last dependent variable in Dozier \& Broom's (1995) model. How do the roles affect this outcome? Interestingly, we detect large heterogeneity when it comes to comparing the four roles. Most remarkably, Diagnosis is strongly related to job satisfaction. Professionals who score well on the Diagnosis factor tend to be much more satisfied with their job than those who score low. Looking at the single items that compose the Diagnosis factor, we can conclude that professionals seem to value tasks that require responsibility, accountability, job diversity and also an analytical, strategic mindset. By contrast, Coaching is negatively connected to job satisfaction. An issue within the coaching role detrimental to job satisfaction might be that these tasks include a lot of cooperation with managers without having any say or participation in decision-making. In the light of social comparison theory, such a coaching function might be associated with constant cognitive awareness of close-by people that have more responsible and more influential roles. The third role, Liaison, does not influence job satisfaction significantly, but Execution - like Diagnosis - has a significant and positive, albeit weak, effect. Thus, professionals also seem to value some of the tasks associated with the Execution factor, such as identifying communication problems or making communication policy decisions. As in the case of Coaching, the Execution factor entails a relatively autonomous and powerful profile, leading to job satisfaction.

Despite substantial influence of the single roles on job satisfaction, the key predictor is participation in management decision-making. Controlling for the manager role and salary, we observe highly significant and positive paths of almost 0.2 . Considering the multifaceted and complex nature of job satisfaction, this is a strong result. It suggests that responsibility and autonomy are important antecedents of a fulfilling job. This seems to be very much 
in accordance with the discussion about providing communication a real voice in corporate decision-making, and shows a strong desire on the side of PR professionals to be taken serious as a value-adding top management function.

\subsubsection{Summary}

Table 3 displays salient differences between the antecedents and effects of the four role factors. In general, we are better able to explain role effects than determinants.

Work experience is the strongest antecedent, with gender, education and PR staff size being less strong in explaining the roles. As for the roles, we best predict Execution, followed by Diagnosis, Coaching, and Liaison. Thus, execution seems to be stronger determined by external and contextual characteristics than the more contingent liaison factor. Looking at the composition of the liaison role, this finding surprises, as the tasks specified in this factor are quite straightforward and largely in line with more technical, operative roles - or the traditional technician role. In general, we are very poor at explaining roles with the model specified by Dozier and Broom (1995), as the low $\mathrm{R}^{2}$ values for all the factors show. In the best case (Execution), we explain around five percent of the total variance in the roles, while in the worst case (Liaison), we hardly explain any variance.

By contrast, the PR roles perform quite well in predicting other constructs. Thus, the model seems to be better able to specify and explain outcomes than antecedents of PR roles. Again, however, we see the Liaison role as more contingent than the more predictive Diagnosis and Coaching roles. While the roles do not differ much in their potential to explain salary, there are large differences for the more intrinsic outcome of job satisfaction. Here, the first two roles - Diagnosis and Coaching - perform better. However, as shown above, Diagnosis is positively associated with job satisfaction, while Coaching enacts a negative influence. 


\section{Conclusion}

Our findings show that in the (Western) European context, PR practitioners exert a large variety of tasks. We classified the tasks into four distinct roles. In sum, a more complex picture emerges than in the original study by Dozier and Broom (1995). A clear dichotomy between managerial and technician roles has been replaced by nuanced differences according to the four bundles of roles. The strong influence of the roles on job satisfaction shows that practitioners' daily activities and the responsibility involved are still very important but more so in intrinsic terms than extrinsic. Thus, enacting stronger diagnostic roles and less execution coincides with high satisfaction but not with higher salary. Although we were able to identify clear effects of the roles, their antecedents are not well able to explain the roles. Neither gender, nor PR staff size or education proved to be strong predictors of the activities. This indicates a blurring or decoupling of the role. Other, less obvious, factors might be more influential in explaining the roles. It might therefore be fruitful to include "softer" and more motivational aspects in the model, such as psychological and personality traits as well as more detailed accounts of the social embedding of actors, e. g. in terms of social network structure.

One of the most important results of the model is that there are no big gender differences between roles. Roles are demographically contingent and more heavily influenced by professional experience and PR staff size than by education and gender. Overall, Coaching is most influenced by demographics and women seem to be more likely to score higher on that factor than men. Secondly, the analysis showed that satisfaction is mostly influenced by participation in management decision-making and not by salary. Execution activities 
have a negative effect on job satisfaction and Coaching activities have a very strong positive effect on job satisfaction.

By scrutinizing those relationships, and by proposing a modernized structural equation model, we believe that our findings have both theoretical and practical relevance. Theoretically, the study contributes to communication profession and roles research, particularly in an European context and with a larger focus on the communication profession. In practical terms, the results provide practitioners as well as academics with insights into the current state and challenges of the communication profession.

Despite the findings, there are several limitations that need to be taken into account. First, there are geographical and cultural limitations, as the selected countries might reflect specific standards of professional PR work in Europe. Duplicating the study in Southern or Eastern Europe, or in other parts of the world, might lead to different results. Second, there are methodological limitations to consider: As mentioned above, considering motivational skills and social embedding of actors might make other methodological approaches necessary. Network Analysis, applied to communication and decision making in PR professionals work environment might lead to more insight in terms of shaping an even more adequate and sophisticated model of role conception.

Third, we think it might even be promising to move research beyond the organizational roles of public relations, and increasingly call for attention to the social roles of public relations (Simoes, 1992;Grunig, 2000), not only due to the findings we present in this study but also according to technological and social developments that are, for example, reflected in the rising importance of social media as tools to improve and enrich internal communica- 
tion, as well as media and stakeholder relations. Here, it would be interesting to consider other important approaches in the PR literature, for instance how the profession is undergoing a transformation of its practices through social media, or a changing, increasingly more active, stakeholder environment. 


\section{Literature cited}

Aldoory, L. \& Toth, E. (2002). Gender Discrepancies in a Gendered Profession: A Developing Theory for Public Relations. Iournal of Public Relations Research, 14(2), 103-126

Berger, B. K. (2005). Power over, power with, and power to relations: Critical reflections on public relations, the dominant coalition, and activism. Iournal of Public Relations Research, 77(1), 5-28.

Berger, B. K. \& Reber, B. H. (2006). Gaining influence in public relations: The role of resistance in practice. Mahwah, NJ: Lawrence Erlbaum Associates.

Berger, B. K., Reber, B. H., \& Heyman, W.C. (2007). You can't homogenize success incommunication management: PR leaders take diverse paths to top. International Journal of Strategic Communication, 1(1), 53-71.

Bollen, K. A. (1989). Structural equations with latent variables. Psychometrika, Vol. 45, 289308

Broom, G. M. (1982). A Comparison of Sex Roles in Public Relations. Public Relations Review, 8(3), 17-22.

Broom, G. M. \& Smith, G. D. (1979). Testing the practitioner's impact on clients, Public Relations Review, 5(3), 47-59.

Byrne, B. (2012). Structural Equation Modeling with Mplus. London: Routledge.

Cameron, G. T., Sallot, L. M. \& Weaver-Lariscy, R. A. (1996). Developing standards of professional performance in public relations. Public Relations Review, 22(1), 43-61.

Choi, J. (2007). Elaborating the Concept of Public Relations Role and a Test of its Utility (Doctoral dissertation). Available from ProQuest Dissertations and Theses databse. (UMI No. 3298030).

DeSanto, B., \& Moss, D. (2004). Rediscovering what PR managers do: Rethinking the measurement of managerial behaviour in the public relations context. Iournal of Communication Management, 9(2), 179-196.

Desanto, B., Moss, D., \& Newman, A. (2007). Building an Understanding of the Main Elements of Management in the Communication / Public Relations Context: A Study of U.S. Practitioners' Practices. Iournalism and Mass Communication Ouarterly, 84(3), 439454.

Dozier, D. M. (1984). Program evaluation and roles of practitioners. Public Relations Review, 10(2), 13-21.

Dozier, D. M. \& Broom, G. M. (1995). Evolution of the Manager Role in Public Relations Practice. Iournal of Public Relations Research, 7(1), 3-26.

Fornell, C., \& Larcker, D. F. (1981). Evaluating Structural Equation Models with Unobservable Variables and Measurement Error. Iournal of Marketing Research, 18(1), 39-50.

Gordon, C. G., \& Kelly, K. S. (1999). Public Relations Expertise and Organizational Effectiveness: A Study of US Hospitals. Journal of Public Relations Research, 77(2), 143-165. 
Gregory, A. \& Willis, P. (2013). Strategic Public Relations Leadership. London: Routledge.

Grunig, J. E. (2000). Collectivism, collaboration, and societal corporatism as core professional values in public relations. Iournal of Public Relations Research, 12(1), 23-48.

Grunig, L. A., Grunig, J. E., \& Dozier, D. M. (2002). Excellent public relations and effective organizations: A study of communication management in three countries. Hillsdale, NJ: Lawrence Erlbaum Associates.

Kaiser, H. F. \& Rice, J. (1974). Little Jiffy, Mark IV. Educational and Psuchological Measurement, 34(April), 111-117.

Lauzen, M. M. \& Dozier, D. M. (1992). The missing link: The public relations manager role as a mediator of organizational environments and power consequences for the function. Iournal of Public Relations Research, 4(4), 205-220.

Leichty, G. \& Springston, J. (1996). Elaborating Public Relations Roles. Iournalism Ouarterly, 73(2), 467-477.

Moss, D. \& Green, R. (2001). Re-examining the manager's role in public relations: What management and public relations research teaches us. Iournal of Communication Management, 6(2), 118-132.

Moss, D., Newman, A., \& DeSanto, B. (2005). What do Communication Managers Do? Defining and Refining the Core Elements of Management in a Public Relations / Corporate Communication Context. Lournalism and Mass Communication Ouarterlu, 82(4), 873890.

Moss, D., Warnaby, G. \& Newman, A., (2000). Public relations practitioner role enactment at the senior management level within UK companies. Iournal of Public Relations Research, 12(4), 277-307.

Netemeyer, R. G., Bearden, W. O., \& Sharma, S. (2003). Scaling Procedures. Issues and Applications. London: Sage.

Nunnally, J. C. (1978). Psychometric theory (2nd ed.). New York: McGraw-Hill.

Porter, L. V. \& Sallot, L. M. (2003). The Internet and public relations: Investigating practitioners' roles and World Wide Web use. Lournalism and Mass Communication Ouarterly, $80(3), 603-622$.

Simoes, R. P. (1992). Public relations as a political function: A Latin American view. Public Relations Review, 18(2), 189-200.

Tench, R., Zerfass, A., Verhoeven, P., Verčič, D., Moreno, A., \& Okay, A. (2013). Communication Management Competencies for European Practitioners. Leeds, UK: Leeds Metropolitan University.

Toth, E. L., Serini, S. A., Wright, D. K., \& Emig, A. G. (1998). Trends in public relations roles: 1990-1995. Public Relations Review, 24(2), 145-163.

Zerfass, A., Verhoeven, P., Tench, R., Moreno, A., \& Verčič, D. (2011). European Communication Monitor 2011. Empirical Insights into Strategic Communication in Europe. Results of an Empirical Survey in 43 Countries (Chart Version). 
Figure 1:

Dozier and Broom's PR model (1995)

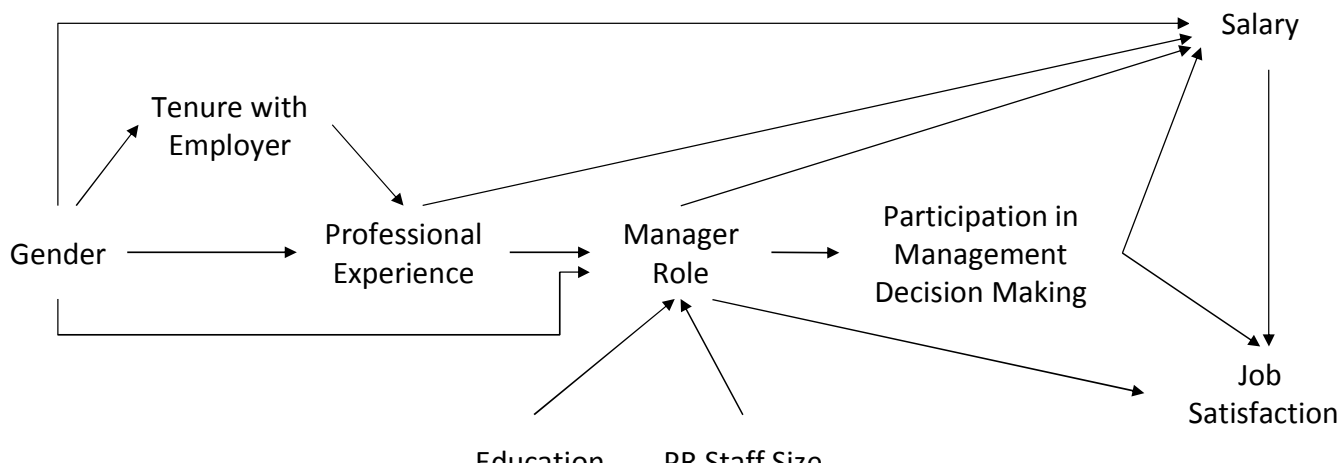

Education PR Staff Size

(c) Emerald $\stackrel{1}{\text { Group Publishing Limited }}$

This is a pre-print of a paper and is subject to change before publication. This pre-print is made available with the understanding that it will not be reproduced or stored in a retrieval system without the permission of Emerald Group Publishing Limited. 
Table 1

Sample Description, Percentages

\begin{tabular}{lccccc}
\hline & $\begin{array}{c}\text { Overall } \\
\text { Percent } \\
\text { (absolute) }\end{array}$ & $\begin{array}{c}\text { Gender: } \\
\text { Male } \\
\text { Percent } \\
\text { (absolute) }\end{array}$ & $\begin{array}{c}\text { Age: } \\
\text { Average } \\
\text { (Stdev.) }\end{array}$ & $\begin{array}{c}\text { Degree: } \\
\text { Master } \\
\text { Percent } \\
\text { (absolute) }\end{array}$ & $\begin{array}{c}\text { Work } \\
\text { Experience: } \\
\text { Average } \\
\text { (Stdev.) }\end{array}$ \\
\hline Austria & 3.9 & 39.1 & 35.0 & 65.2 & 10.5 \\
Belgium & $(23)$ & $(9)$ & $(8.2)$ & $(15)$ & $(7.8)$ \\
France & 11.1 & 48.4 & 39.6 & 58.5 & 10.6 \\
Germany & $(65)$ & $(31)$ & $(8.7)$ & $(38)$ & $(7.3)$ \\
Luxembourg & 9.7 & 36.8 & 41.4 & 80.7 & 12.7 \\
Netherlands & $(57)$ & $(21)$ & $(8.1)$ & $(46)$ & $(7.9)$ \\
Switzerland & 9.2 & 50.0 & 39.6 & 81.5 & 11.7 \\
\multirow{2}{*}{ United Kingdom } & $(54)$ & $(27)$ & $(9.1)$ & $(44)$ & $(8.2)$ \\
& 2.2 & 46.2 & 39.6 & 84.6 & 9.3 \\
& $(13)$ & $(6)$ & $(7.9)$ & $(11)$ & $(4.8)$ \\
Total & 14.8 & 52.3 & 40.8 & 67.4 & 12.6 \\
& $(87)$ & $(45)$ & $(8.9)$ & $(58)$ & $(8.0)$ \\
& 24.3 & 53.6 & 40 & 72.0 & 12.0 \\
& $(143)$ & $(75)$ & $(8.0)$ & $(103)$ & $(7.5)$ \\
& $(146)$ & $(64)$ & $(8.9)$ & $(46)$ & $(7.8)$ \\
\hline
\end{tabular}


Table 2

Measurement Model

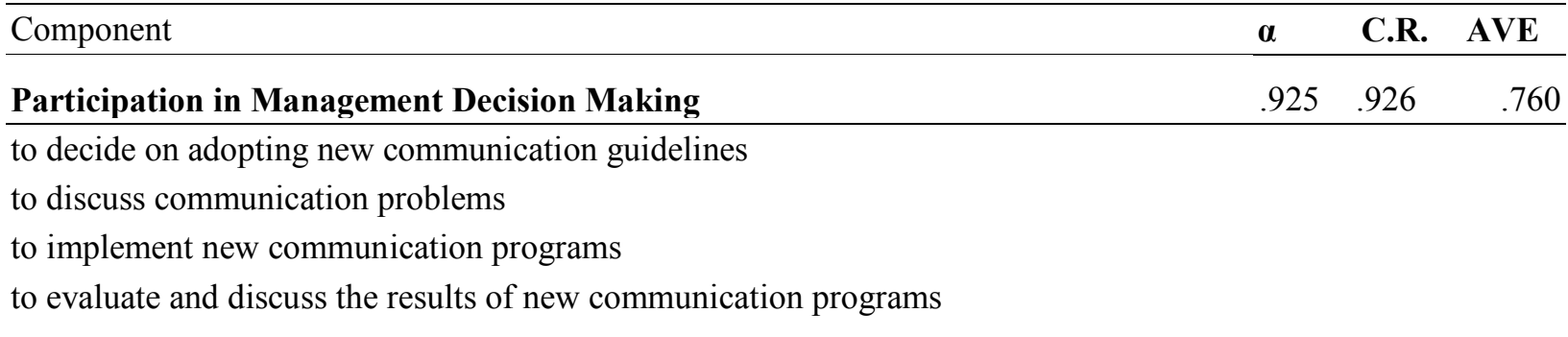

\begin{tabular}{llrr}
\hline Job Satisfaction & .963 & .961 & .892 \\
\hline
\end{tabular}

I like doing the things I do at work

I feel a sense of pride in doing my job

My job is enjoyable

\section{PR Roles}

Diagnosis

$.921 \quad .851$

.656

Others in my organization consider me an expert at solving communication problems.

I diagnose communication problems and explain them to others.

I keep management informed of public reactions.

I take responsibility for the success or failure of my organization's communication program.

I observe that others in the organization hold me accountable for the success and the failure of our communication.

I plan and recommend courses of action for solving communication problems.

I monitor and report on diverse media channels and keep management informed of the publics' opinions.

I frame and place content for publication in various media channels.

I carry out research and distribute relevant content and coverage.

I forward media enquiries to the right person in my organization.

\begin{tabular}{lrrr}
\hline Coaching & .855 & .840 & .636 \\
\hline
\end{tabular}

When working with managers on communication topics, I outline alternative approaches for solving problems.

I work with managers to increase their skills in solving and/ or avoiding communication problems.

I encourage management participation when making important communication decisions.

\begin{tabular}{lrrr}
\hline Liaison & .841 & .836 & .630
\end{tabular}

I maintain media contacts and place press releases.

I handle the organizational aspects of producing presentations and press releases.

I produce communication content for publication.

Execution

.778

I organize events to expose management to the views of various publics.

I identify communication problems between my organization and various publics.

I make the communication policy decisions. 
Table 3

Models according to Factors

\begin{tabular}{|c|c|c|c|c|c|}
\hline Relationship & $\begin{array}{l}\text { Coefficient } \\
\text { Factor 1: } \\
\text { "Diagnosis" }\end{array}$ & $\begin{array}{l}\text { Coefficient } \\
\text { Factor 2: } \\
\text { "Coaching" }\end{array}$ & $\begin{array}{l}\text { Coefficient } \\
\text { Factor 3: } \\
\text { "Liaison" }\end{array}$ & $\begin{array}{c}\text { Coefficient } \\
\text { Factor 4: } \\
\text { "Execution" }\end{array}$ & Avg. \\
\hline $\begin{array}{l}\text { Gender } \rightarrow \\
\text { Tenure }\end{array}$ & $.10 * *$ & $.10 * * *$ & $.10 * * *$ & $.10 * * *$ & .10 \\
\hline $\begin{array}{l}\text { Gender } \rightarrow \\
\text { Professional Experience }\end{array}$ & $.14 * * *$ & $.13 * * *$ & $.14 * * *$ & $.14 * * *$ & .14 \\
\hline $\begin{array}{l}\text { Gender } \rightarrow \\
\text { Salary }\end{array}$ & $.16 * * *$ & $.16^{* * *}$ & $.16^{* * *}$ & $.15 * * *$ & .16 \\
\hline $\begin{array}{l}\text { Tenure } \rightarrow \\
\text { Professional Experience }\end{array}$ & $.36 * * *$ & $.36^{* * *}$ & $.36 * * *$ & $.36 * * *$ & .36 \\
\hline $\begin{array}{l}\text { Professional Experience } \rightarrow \\
\text { Salary }\end{array}$ & $.27 * * *$ & $.26 * * *$ & $.27 * * *$ & $.26 * * *$ & .27 \\
\hline $\begin{array}{l}\text { PIMDM } \rightarrow \\
\text { Salary }\end{array}$ & $.08 *$ & $.08 *$ & n. s. & n. $\mathrm{s}$. & .08 \\
\hline $\begin{array}{l}\text { PIMDM } \rightarrow \\
\text { Job Satisfaction }\end{array}$ & $.13 * * *$ & $.16^{* * *}$ & $.18 * * *$ & $.17 * * *$ & .16 \\
\hline $\begin{array}{l}\text { Salary } \rightarrow \\
\text { Job Satisfaction }\end{array}$ & $.08 *$ & n. $\mathrm{s}$. & $.08^{*}$ & $.08 *$ & .08 \\
\hline \multicolumn{6}{|l|}{ Focus on the Managerial Role } \\
\hline $\begin{array}{l}\text { Gender } \rightarrow \\
\text { Manager Role }\end{array}$ & n. s. & n. s. & n. s. & $.07 *$ & n. s. \\
\hline $\begin{array}{l}\text { Professional Experience } \rightarrow \\
\text { Manager Role }\end{array}$ & $.13 * * *$ & n. s. & n. s. & $.16^{* * *}$ & - \\
\hline $\begin{array}{l}\text { Education } \rightarrow \\
\text { Manager Role }\end{array}$ & n. s. & n. s. & n. s. & $-.11 * *$ & - \\
\hline $\begin{array}{l}\text { PR Staff Size } \rightarrow \\
\text { Manager Role }\end{array}$ & n. $\mathrm{s}$. & $-.09 *$ & n. $s$. & n. $\mathrm{s}$. & - \\
\hline $\begin{array}{l}\text { Manager Role } \rightarrow \\
\text { PIMDM }\end{array}$ & $.13 * * *$ & n. s. & $.17 * * *$ & $.20 * * *$ & - \\
\hline $\begin{array}{l}\text { Manager Role } \rightarrow \\
\text { Salary }\end{array}$ & n. $s$. & $-.12 * * *$ & n. $\mathrm{s}$. & $.08 *$ & - \\
\hline $\begin{array}{l}\text { Manager Role } \rightarrow \\
\text { Job Satisfaction }\end{array}$ & $.30 * * *$ & $-.13 * * *$ & $-.08^{*}$ & n. s. & - \\
\hline \multicolumn{6}{|l|}{$\mathbf{R}^{2}$} \\
\hline $\mathrm{R}^{2}$ Tenure & .01 & .01 & .01 & .01 & .01 \\
\hline $\mathrm{R}^{2}$ Professional Experience & .16 & .16 & .16 & .16 & .16 \\
\hline $\mathrm{R}^{2}$ Manager Role & .02 & .01 & .01 & .05 & \\
\hline $\begin{array}{l}\mathrm{R}^{2} \text { Participation Management } \\
\text { Decision Making }\end{array}$ & .02 & .003 & .03 & .04 & .02 \\
\hline $\mathrm{R}^{2}$ Salary & .12 & .13 & .12 & .13 & .13 \\
\hline $\mathrm{R}^{2}$ Job Satisfaction & .13 & .05 & .04 & .04 & .06 \\
\hline
\end{tabular}

